\title{
A Modified Price-Sales Ratio: A Useful Tool For Investors?
}

David R. Vruwink, (E-mail: dvruwink@ksu.edu), Kansas State University Jeffrey J. Quirin, (E-mail: jeffrey.quirin@ wichita.edu), Wichita State University David O’Bryan, (E-mail: obryan@ @ittstate.edu), Pittsburg State University

\begin{abstract}
This study compares returns for stock portfolios using low price-to-earnings, price-to-book, price-tosales, and price-to-sales ratios modified for profitability of sales and long-term debt. Non-financial companies with fiscal years ending on December 31 were included in a sample covering a 17-year period (1988-2004). The resulting sample was sub-divided into six groups by level of market capitalization. A 25 stock portfolio was then compiled for each of six valuation ratios at each level of market capitalization. An index portfolio was also computed for each level of market capitalization. First, the results of this study showed that additional expected returns based on firm size, measured by the market value of equity, is found only at the micro-cap level (less than \$25 million market capitalization). The index portfolios of mini-caps (\$25-100 mill.), small caps (\$100-500 mill.), and mid-caps (\$500-\$1 bill.) did not show any additional returns in comparison to the large-cap index portfolio. Second, no "value" portfolio for mid-caps provided significant returns above the index portfolio, suggesting a much greater level of market efficiency at this level of market capitalization. Finally, the most significant findings of our study were that the portfolios constructed from low priceto-sales and modified price-to sales ratios performed as well or better than the more traditional priceto-earnings and price-to-book ratios. The price-to-sales ratio adjusted for profit margin (based on the prior three years) was statistically significant in three of six portfolios in comparison to the more traditional valuation ratios.
\end{abstract}

\section{INTRODUCTION}

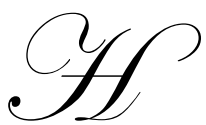

istorically, the market price-to-earnings (P/E) ratio and the market price-to-book value of equity (P/B) ratio have been used by investors for equity valuations and to subsequently guide them during their stock selection decisions (Penman et al. 2005, Leibowitz 2002). The conventional wisdom, backed by numerous academic studies, is that investors who select stocks with low $\mathrm{P} / \mathrm{E}$ ratios and low $\mathrm{P} / \mathrm{B}$ ratios will earn aboveaverage rates of return with their stock portfolios (Nissim and Penman 1999). Investment and financial magazines usually publish lists of stocks with low $\mathrm{P} / \mathrm{B}$ and $\mathrm{P} / \mathrm{E}$ ratios in order to help their readers find stocks that have a high probability of above-average returns. Although work by Lundholm and O'Keefe (2001) suggests that there is little to be gained by the empirical comparison of stock valuation models, subsequent evidence presented by Penman (2001) indicate that this claim is misguided. Specifically, Penman (2001) shows that depending on the investment or valuation horizon the type of valuation model used is pertinent to proper equity valuation. Moreover, Penman (2006) asserts that equity valuation and prediction models need to be "handled with care", as they are merely mathematical models that can convey a false sense of precision.

Fisher (1984) popularized a third financial ratio, the market price-to-sales $(\mathrm{P} / \mathrm{S})$ ratio, which has been increasingly used by investors for selecting stocks in recent years. The P/S ratio measures how much an investor is willing to pay for each dollar of sales. Fisher argues that the P/S ratio is a very good indicator of a stock's popularity. Stocks of companies with high P/S ratios are very popular with investors but are unlikely to earn long-term, aboveaverage returns because of their high stock price in relation to sales. Conversely, stocks with low P/S ratios are more likely to earn long-term, above-average rates of return because any improvement in a company's performance, (e.g., an unexpected increase in earnings or sales) will significantly boost the stock's popularity with investors. 
While the P/S ratio appears to be a very useful tool in explaining stock returns, it still possesses some limitations. A review of any list of low P/S stocks shows that most of these companies have chronic low profitability or high levels of debt. An investor looking for one or two stocks would find these lists of low P/S stocks of limited usefulness because of the high levels of risk associated with the individual companies. Thus, the primary goal of this study is to modify the $\mathrm{P} / \mathrm{S}$ ratio for profitability and level of debt so that higher quality companies can be identified as potentially undervalued to investors. This goal will be achieved by compiling stock portfolios using modified P/S ratios and comparing their returns with the returns of stock portfolios based on traditional P/E, P/B, and P/S stock selection strategies. If equal or greater returns can be achieved through a stock selection strategy utilizing modified P/S portfolios, individual investors may deem the modified $\mathrm{P} / \mathrm{S}$ selection technique as a valuable screening tool for finding undervalued companies.

\section{LITERATURE REVIEW AND HYPOTHESES DEVELOPMENT}

\section{Traditional Ratio Valuation}

The results of a comprehensive study by Fama and French (1992) have been generally accepted by the academic world in finance as to determining what financial or accounting information have the strongest relationship with expected stock returns. The authors found that the book-to-market value of equity and firm size, measured by the market value of equity, were the most highly correlated with average stock returns during the 1963-1990 period. Additional findings revealed that a stock's beta does not possess significant explanatory power, and the combination of a stock's (1) book-tomarket value of equity and (2) firm size absorbs the roles of financial leverage and the earnings/price ratio in explaining stock returns. In a subsequent replication and extension, these initial book-to-market and firm size findings were supported by Davis et al. (2000) in a study spanning nearly 70 years (1929-1997).

In follow-up studies, Fama and French $(1993,1995)$ and Davis et al. (2000) provided economic rationales for their findings by showing that the book-to-market value of equity ratio and firm size are proxies for a stock return's sensitivity to risk factors. Companies that are smaller or have a relatively high book-to-market value ratio tend to experience weaker economic and financial performance than do companies with the opposite characteristics. Based on this logic, the higher returns associated with the stocks of these companies can be regarded as compensation for the assumption of greater risk.

An additional study by O'Shaughnessy (1997) covered a somewhat longer period as well (1951-1994). He found that most of the excess returns associated with smaller stocks were primarily from companies with a market capitalization of less than $\$ 25$ million. Additional returns rapidly decreased as the market capitalization of portfolios increased to $\$ 500$ million. In addition, O'Shaughnessy's results revealed that actual returns of a portfolio of all stocks with a market capitalization of $\$ 500$ million to $\$ 1$ billion had slightly lower returns than a portfolio of all stocks with a market capitalization of more than $\$ 1$ billion. While O'Shaughnessy's results support Fama and French's (1992) and Davis et al.'s (2000) findings on the relationship between firm size and expected returns, it also displays how the relationship is skewed toward the very smallest market capitalization of stocks.

In addition to the aforementioned findings, O'Shaughnessy also reports that a stock portfolio containing companies with low P/B ratios outperformed all other stock selection strategies except for one utilizing a low P/S ratio. Similarly, in a study covering a 13-year time period (1979-1991), Barbee et al. (1996) found that a portfolio of low P/S stocks (.0259 monthly return) greatly outperformed a portfolio of low P/B stocks (.0164 monthly return). Finally, Jensen et al. (1998) compared the results of investment portfolios based upon low P/S, P/E, P/B, and price-to-cash flow ratios covering a 32-year period (1963-1995). The mean returns and standard deviations of returns of all the portfolios formulated by the various ratios were quite similar. This suggests that the P/S ratio was at least comparable to the other value ratios over an extended period of time. In aggregate, these findings do provide some support for the usefulness of the $\mathrm{P} / \mathrm{S}$ ratio. 


\section{The Price-Sales Ratio}

A broader use of the P/S ratio began to appear in the early 1980's, when it was used to identify companies that were likely to be taken over because of low market valuation. The P/S ratio is computed by dividing a company's last twelve months sales by the total number of shares outstanding. The market price of the stock is then compared to the amount of sales per share. For example, a company with $\$ 100$ million in sales and 10 million shares outstanding would have sales of $\$ 10$ per share. If the market price of the stock is currently $\$ 20$, the $\mathrm{P} / \mathrm{S}$ ratio would be $2(\$ 20 / \$ 10$ sales per share), and indicates that investors are willing to pay $\$ 2$ for each $\$ 1$ of sales. The $\mathrm{P} / \mathrm{S}$ ratio of 2 for this company could then be compared with the $\mathrm{P} / \mathrm{S}$ ratios of other companies in the same industry. The companies with the lowest $\mathrm{P} / \mathrm{S}$ ratios in the industry would then be identified as the most likely to earn above average returns because of their low market valuation in relation to sales.

Fisher's (1984) theory suggests that investors should only purchase stock in the companies with low P/S ratios because each invested dollar will then buy more dollars of sales and result in a higher probability of greater returns for an investor's stock portfolio. Fisher argues that identifying low P/S companies is an important first step in achieving above average returns with investment portfolios and suggests that the P/S ratio is a more useful indicator of under-valued stocks than the P/E ratio because a company's annual sales is usually much more stable than it's reported earnings. Evidence of earning instability is readily apparent in the market as earnings for most companies are inherently unstable due to changes in economic or industry conditions. In addition, numerous studies have shown it is very difficult for financial analysts to predict how sustainable a company's current earnings will be in the future. Finally, literature suggests that due to the increased importance of meeting earnings targets in the financial press, companies feel compelled to engage in earnings management or smoothing that often distort financial reality (Dechow 1994).

In the last twenty years, the $\mathrm{P} / \mathrm{S}$ ratio may have also became a more useful stock return predictor due to the rapid development of intangible assets (e.g., intellectual capital) that are often a company's most valuable assets. These intangibles, which are often not reflected in the balance sheet (and subsequently not in book value), should appear in the income statement as increased revenues. For example, both Microsoft and Cisco Systems have developed enormous amounts of intangible assets during recent years. These intangible assets have given both companies a competitive edge in doing business. Current accounting standards do not allow either Microsoft or Cisco Systems to recognize these intangible assets unless purchased from another company. Furthermore, any costs made toward the development of these intangible assets must be expensed. This process may lead to an understatement of the book value of shareholders' equity for these types of companies and subsequently make the P/B ratio less meaningful to investors. A company's superior intangible assets or intellectual capital should, however, eventually be reflected in rapidly growing sales. Thus, the P/S ratio is potentially superior to the $\mathrm{P} / \mathrm{B}$ ratio because sales may better reflect the true market value of the firm.

\section{A Modified Price-Sales Ratio}

The $\mathrm{P} / \mathrm{S}$ ratio may not be a perfect indicator of a stock's popularity with investors because the ratio fails to focus on a company's earnings which is the predominate valuation metric in the contemporary financial press. It is believed that an investor seeking long-term, abnormal returns would be best served to invest in companies in highly-profitable industries. In theory, if the P/S ratio could be adjusted for differing levels of profitability of each dollar of sales, the resulting adjusted $\mathrm{P} / \mathrm{S}$ ratio would be more consistent with contemporary investment strategy and better reflect a stock's popularity with investors.

One possible procedure is to assume that the average company has a profit margin of five percent on each dollar of sales. Companies with higher (lower) profit margins could have their P/S ratio decreased (increased) to reflect the higher (lower) amount that investors are paying for the profitability of sales. For example, a company with an average profit margin of ten percent would have its P/S ratio multiplied by $.5(.05 / .10)$ to adjust for the higher value of each dollar of sales. Consequently, a company with a $21 / 2$ percent profit margin would have its $\mathrm{P} / \mathrm{S}$ ratio multiplied by two $(.05 / .025)$ to reflect the lower value of each sales dollar. The two companies' adjusted P/S ratios are much more comparable in terms of their popularity with investors since the portion of the $\mathrm{P} / \mathrm{S}$ ratio related to profitability has now been removed. 
A second modification to the P/S ratio suggested by this study accounts for the varying degrees of financial leverage that are used by companies. Any list of companies with low P/S ratios will reveal companies with large quantities of long-term debt. Since these companies are choosing to substitute debt for equity, investors are being rational in paying a lower market price per dollar of sales for the common stock because a portion of the profits from a percentage of sales is being used to finance long-term debt. Thus, the "private enterprise value" will be used to appropriately adjust the $\mathrm{P} / \mathrm{S}$ ratio. Private enterprise reflects the total value of the company's equity and debt. The " $\mathrm{P}$ ", or price, portion of the ratio is adjusted to include both the market price of equity per share and the long-term debt per share.

\section{Hypotheses}

Several hypotheses will be tested in this study. First, the returns from the stock portfolios formulated with a modified $\mathrm{P} / \mathrm{S}$ ratio strategy will be compared with the returns from numerous index portfolios segmented according to market capitalization to determine whether the valuation methods based on the modified $\mathrm{P} / \mathrm{S}$ ratios are valid investment strategies. If the portfolios based on the modified $\mathrm{P} / \mathrm{S}$ ratios do show significant returns in comparison to the appropriate index portfolios, these results would support additional research on the profitability of sales and/or long-term debt being a significant factor in explaining the valuation of a firm. Thus, the first hypothesis stated in the alternative form is:

H1: The stock portfolios based on a modified P/S selection strategy will yield significantly higher returns than the index stock portfolios.

Next, the returns from the stock portfolios based on the modified P/S strategy will be compared with the returns of stock portfolios based on the more traditional (P/E and P/B) stock selection techniques. Significantly greater returns by the modified P/S portfolios would indicate that investors could earn greater returns by focusing on what they pay for each adjusted dollar of sales rather than what they pay for each dollar of earnings or book value. Therefore, the second alternative hypothesis results:

H2: The stock portfolios based on a modified P/S selection strategy will yield significantly higher returns than stock portfolios formulated with the more traditional P/E and P/B selection strategies.

Finally, the returns from the stock portfolios based on the modified P/S selection methods will be compared with the returns of stock portfolios formed using a basic P/S ratio procedure. Significantly greater returns by the modified P/S portfolios would indicate that investors might be able to earn greater returns by adjusting the $\mathrm{P} / \mathrm{S}$ ratio for profitability of sales and long-term debt. The third alternative hypothesis results:

H3: The stock portfolios based on a modified P/S selection strategy will yield significantly higher returns than stock portfolios formulated with the basic P/S selection strategy.

\section{RESEARCH METHODOLOGY}

\section{Data And Sample}

Data to test the research hypotheses was gathered from the 2005 version of Compustat PC Plus. A company, to be included in the study, was required to have a December 31 fiscal year-end, not be classified as a financial or financial services firm, and have all the required accounting and financial data (i.e., stock price, earnings per share, book value of equity, etc.) for each year of the study. The 2005 Compustat database initially contained a total of 19,548 firms in the combined current and research tapes. Of this amount, 7,487 firms had a fiscal December 31 year-end. The exclusion of financial firms reduced the sample to 6,112 companies. The remaining sample mortality for each year was due to a lack of required return and/or accounting-related data. 
Data was collected for a 20-year period (1986-2005). Valuation ratios were constructed at December 31 of each year. In this study, the $\mathrm{P} / \mathrm{S}$ ratios adjusted for profitability require a 3 -year average net profit margin on sales. Thus, the valuation ratios were constructed only for the 1988-2004 period. To control for the influence of firm size, sample firmyear observations were placed into six portfolios according to the market capitalization of the company at the December 31 fiscal year-end. Portfolios included micro-caps (less than $\$ 25$ million market capitalization), mini-caps (market capitalization between $\$ 25$ to $\$ 100$ million), small-caps ( $\$ 100$ to $\$ 500$ million market capitalization), mid-caps (market capitalization between $\$ 500$ to $\$ 1$ billion), large-caps (a market capitalization of more than $\$ 1$ billion), and all-caps (market capitalization of more than $\$ 100$ million).

To test which stock selection strategy resulted in the highest annual return, portfolios consisting of 25 stocks were constructed annually for each ratio approach within each capitalization segment. For example, the 25 micro-cap stocks having the lowest $\mathrm{P} / \mathrm{E}$ ratios each year represented the low $\mathrm{P} / \mathrm{E}$ portfolio while the 25 micro-cap stocks having the lowest $\mathrm{P} / \mathrm{S}$ ratios each year represented the low $\mathrm{P} / \mathrm{S}$ portfolio. ${ }^{1}$ Portfolios were reconstructed each year to ensure that the best stocks (according to the appropriate investment strategy) were included in each valuation portfolio. Annual cumulative stock returns were then calculated for each portfolio using the subsequent April 1 to March 31 period. Companies are required to report fiscal year end financial data by 90 days to the SEC, thus, necessitating a lag in the return period.

\section{Portfolio Variables}

This section defines the valuation ratios used for the purposes of hypotheses testing.

\begin{tabular}{|c|c|c|}
\hline $\mathrm{E} / \mathrm{P}$ ratio $_{\text {it }}$ & $=$ & $\mathrm{E}_{\mathrm{it}} / \mathrm{P}_{\mathrm{it}}$ \\
\hline where $E_{i t}$ & $=$ & Earnings per share for firm $\mathrm{i}$, year $\mathrm{t}$. \\
\hline $\mathrm{P}_{\mathrm{it}}$ & $=$ & Price per share for firm i, year $\mathrm{t}$. \\
\hline $\mathrm{B} / \mathrm{P}$ ratio $_{\text {it }}$ & $=$ & $\mathrm{B}_{\mathrm{it}} / \mathrm{P}_{\mathrm{it}}$ \\
\hline where $B_{\text {it }}$ & $=$ & Book value per share for firm $i$, year $t$. \\
\hline $\mathrm{S} / \mathrm{P}$ ratio $_{\text {it }}$ & $=$ & $\mathrm{S}_{\mathrm{it}} / \mathrm{P}_{\mathrm{it}}$ \\
\hline where $S_{\text {it }}$ & $=$ & Sales per share for firm i, year $\mathrm{t}$. \\
\hline $\mathrm{S} / \mathrm{P}+\mathrm{D}$ ratio $_{\text {it }}$ & $=$ & $\mathrm{S}_{\mathrm{it}} /\left(\mathrm{P}_{\mathrm{it}}+\mathrm{D}_{\mathrm{it}}\right)$ \\
\hline where $D_{\text {it }}$ & $=$ & Long-term debt per share for firm i, year $t$. \\
\hline $\mathrm{PMS} / \mathrm{P}$ ratio $_{\text {it }}$ & $=$ & $\left(\mathrm{S}_{\mathrm{it}} / \mathrm{P}_{\mathrm{it}}\right) /\left(\mathrm{PM}_{\mathrm{it}} / .05\right)$ \\
\hline where $\mathrm{PM}_{\mathrm{it}}$ & $=$ & Three-year average profit margin for firm i, year $t$. \\
\hline $\mathrm{PMS} / \mathrm{P}+\mathrm{D}$ ratio $_{\mathrm{it}}=$ & {$\left[\mathrm{S}_{\mathrm{i}}\right.$} & $\left.\left.+\mathrm{D}_{\mathrm{it}}\right)\right] /\left[\mathrm{PM}_{\mathrm{it}} / .05\right]$ \\
\hline
\end{tabular}

\footnotetext{
${ }^{1}$ Consistent with prior literature, the authors constructed each valuation ratio with price as the denominator rather that the numerator. For example, the results of this paper reflect portfolios based upon high E/P ratios rather than low $\mathrm{P} / \mathrm{E}$ ratios. This was done in order to eliminate extremely high $\mathrm{P} / \mathrm{E}$ or $\mathrm{P} / \mathrm{B}$ ratios due to abnormally small earnings or book value levels.
} 


\section{EMPIRICAL RESULTS}

\section{Analysis Of Portfolio Returns}

The actual returns for each type of portfolio and the standard deviations of those returns are summarized in Table 1. In the first column of Table 1, the returns of the index portfolios are shown at each level of market capitalization. The micro-cap index portfolio earned the highest average return of $25.2 \%$, while the small-cap portfolio had the lowest average return of 9.2\%. The micro-cap returns were similar to O'Shaughnessy's (1997) results (25.12\% average return) and support his contention that only at the micro-cap level will investors earn significantly greater returns due to simply owning smaller stocks (firm size).

Interestingly, the large-cap index portfolio has both a higher return and a smaller standard deviation than the other three remaining index portfolios: (mini-cap, small-cap, and mid-cap) which consist of much smaller market-cap stocks. O'Shaughnessy's (1997) results depicted a scenario where only the mid-cap portfolio had lower returns than the large-cap portfolio.

The traditional low $\mathrm{P} / \mathrm{E}$ and $\mathrm{P} / \mathrm{B}$ portfolios had greater returns than the index portfolios at the various levels of market capitalization. In addition, the value portfolios usually had lower levels of standard deviation of returns in comparison to the index portfolios. The low P/E strategy worked best at the mini-cap and small-cap levels, while the low P/B strategy worked best at the large-cap level. Again, O'Shaughnessy's (1997) results differed in that he found that the low P/E strategy worked best at the large-cap level.

The low P/S portfolios had much higher returns than the index and traditional value portfolios except at the midcap level. However, the returns of the low P/S portfolios had much greater standard deviations than the other portfolios. A potential explanation for these results is that the low $\mathrm{P} / \mathrm{S}$ strategy selects companies that possess more risk than the companies selected under a low P/E or low P/B strategy.

Of the three modified P/S selection strategies, the low P/S (adjusted for profit margins) portfolios resulted in some of the highest returns in the study. This strategy resulted in the highest returns at the micro-cap, small-cap, midcap, large-cap, and all-cap levels of market capitalization. Thus, the profitability of each dollar of sales does appear to matter to investors. Although the portfolios utilizing the other modified P/S strategies had much lower returns, they still outperformed the index portfolios. These lower returns can be explained by the components of ratios themselves. By including long-term debt with the market value of equity in the computation of these modified P/S ratios, the selected companies were much more likely to be more financially stable and much less risky.

\section{Hypotheses Testing}

Table 2 reports t-statistics for mean return comparisons of each selection strategy at the various levels of market capitalization. The t-statistics presented in Panel A represent comparisons of the returns and the variance of those returns for the index portfolios versus the six portfolios computed using the different selection strategies. In Panel A, a negative t-statistic indicates that the competing portfolio method is superior to the index strategy. The low P/E portfolios have significantly higher returns within the three smallest market-cap and the all-cap segments, while the low P/B portfolios have significantly higher returns only at the micro-cap and large-cap portfolios. The four portfolios using the $\mathrm{P} / \mathrm{S}$ ratio show superior returns over a much wider range of market capitalization with the exception of the mid-cap portfolios. Consistent with hypothesis 1 , the modified $\mathrm{P} / \mathrm{S}$ ratio strategies significantly outperformed the index in the majority of the cases. These results, coupled with the basic P/S findings, provide support for the use of the P/S ratio (in basic and modified forms) as a sound investment strategy. Additionally, the results suggest that a selection strategy utilizing the P/B ratio may be declining in usefulness in comparison to other selection methods.

Panel B presents t-statistics that compare the returns and variance of those returns for the low $\mathrm{P} / \mathrm{E}$ portfolio with the other value portfolios. Similar to Panel A, a negative t-statistic implies that the competing portfolio strategy is superior to the $\mathrm{P} / \mathrm{E}$ portfolio strategy. Only for the large-cap portfolios did the other value portfolios consistently show 
statistically better results than the low $\mathrm{P} / \mathrm{E}$ portfolios. The low $\mathrm{P} / \mathrm{S}$ (adjusted for profit margin) selection method was the only strategy to statistically outperform the low P/E ratio for three of the six market-cap segments. Similar results are presented in Panel C, where the low $\mathrm{P} / \mathrm{B}$ portfolio returns and variance of those returns are compared with the returns and variances of the four alternatives of the low P/S strategy. Although the low P/S (adjusted profit margin) ratio again statistically outperformed the low P/B ratio for three of the six market-cap portfolios, the P/S and modified P/S methods show consistently better results only for the mini-cap portfolios. Coupled with the findings in Panel B, some support is found for hypothesis 2 . The modified P/S investment strategy does outperform the traditional P/E and P/B stock selection strategies in some instances.

The last set of t-statistics contained in Panel D reveals that the low P/S (adjusted for profit margin) strategy outperformed the basic P/S portfolio at the micro-cap level. The other modified P/S strategies failed to outperform the basic P/S selection method in the remaining market capitalization segments. Thus, little support is found for hypothesis 3. In general, a modified P/S stock selection technique cannot be deemed superior to a basic P/S investment strategy.

\section{SUMMARY AND CONCLUSIONS}

First, the results of this study showed that additional expected returns based on firm size, measured by the market value of equity, is found only at the micro-cap level (less than $\$ 25$ million market capitalization). The index portfolios of mini-caps, small caps, and mid-caps did not show any additional returns in comparison to the large-cap index portfolio. These results were similar to O'Shaughnessy's (1997) and question the strategy of investing in index funds for small stocks that have market capitalization greater than $\$ 25$ million. Second, no "value" portfolio for mid-cap stocks provided significant returns above the index portfolio, suggesting a much greater level of market efficiency at this level of market capitalization.

A significant finding of our study was that the portfolios constructed using the low $\mathrm{P} / \mathrm{S}$ and modified $\mathrm{P} / \mathrm{S}$ strategies performed as well or better than portfolios formulated with the more traditional $\mathrm{P} / \mathrm{E}$ and $\mathrm{P} / \mathrm{B}$ ratios, when comparing returns and the variance of those returns against the index portfolios. These findings reinforce the argument that sales, the expected profitability of those sales, and long-term debt are at least of equal importance to a company's earnings or book value of equity in explaining stock returns.

The price-sales ratio adjusted for the profit margins of sales shows the most promise as an alternative investment strategy, especially when comparing its returns with the returns from the more traditional P/E and P/B selection methods. In terms of returns, fifty percent of the P/S (adjusted for profit margins) portfolios were statistically superior to the P/E and P/B portfolios. Since the profit margins used to adjust the P/S ratio were based on the company's average profitability for the prior three years, our findings suggest that this variable deserves more attention in future research. While the results of this study reveal that certain investment strategies (ratios) indeed outperform others, as so eloquently expressed by Penman (2006), any mathematically-based valuation or prediction model should be "handled with care" so that a false sense of precision is not conveyed. 


\section{BIBLIOGRAPHY}

1. Barbee, William C., Sandip Mukherji, and Gary A. Raines. 1996. Do Sales-Price and Debt-Equity Explain Stock Returns Better than Book-Market and Firm Size? Financial Analysts Journal March/April: 56-60.

2. Davis, James L., Eugene F. Fama, and Kenneth R. French. 2000. Characteristics, Covariances, and Average Returns: 1929-1997. Journal of Finance February: 389-406.

3. Dechow, P. 1994. Accounting Earnings and Cash Flows as Measures of Firm Performance: The Role of Accounting Accruals. Journal of Accounting and Economics 18: 3-42.

4. Fama, Eugene F., and Kenneth R. French. 1992. The Cross-Section of Expected Stock Returns. Journal of Finance June: 427-465.

5. Fama, Eugene F., and Kenneth R. French. 1993. Common Risk Factors in the Returns on Stocks and Bonds. Journal of Financial Economics February: 3-56.

6. Fama, Eugene F., and Kenneth R. French. 1995. Size and Book-to-Market Factors in Earnings and Returns. Journal of Finance March: 31-55.

7. $\quad$ Fisher, Kenneth L. 1984. Super Stocks. Homewood, Illinois: Dow Jones-Irwin.

8. Jensen, Gerald R., Robert R. Johnson, and Jeffrey M. Mercer. 1998. The Inconsistency of Small-Firm and Value Stock Premiums. The Journal of Portfolio Management Winter: 27-36.

9. Leibowitz, Martin L. 2002. The Levered P/E Ratio. Financial Analysts Journal November/December: 6877.

10. Lundholm, Russell J., and Terry O'Keefe. 2001. Reconciling Value Estimates from the Discounted Cash Flow Model and the Residual Income Model. Contemporary Accounting Research Summer: 1-26.

11. Nissim, Doron, and Stephen H. Penman. 1999. Ratio Analysis and Equity Valuation. Unpublished Working Paper. Columbia University - Department of Accounting.

12. O'Shaughnessy, James. P. 1997. What Works on Wall Street New York: McGraw-Hill.

13. Penman, Stephen H. 2001. On Comparing Cash Flow and Accrual Accounting Models for Equity Valuation. Contemporary Accounting Research Fall: 681-692.

14. Penman, Stephen H. 2006. Handling Valuation Models. Journal of Applied Corporate Finance Spring: 4855 .

15. Penman, Stephen H., Scott A. Richardson, and A. Irem Tuna. 2005. The Book-to-Price Effect in Stock Returns: Accounting for Leverage. Unpublished Working Paper. Columbia University - Department of Accounting. 
TABLE 1

SUMMARY OF AVERAGE RETURNS

FOR ALL PORTFOLIOS

1988-2004

\begin{tabular}{|c|c|c|c|c|c|c|c|c|c|c|c|c|c|c|}
\hline \multirow[b]{2}{*}{$\begin{array}{l}\text { Micro-cap } \\
<\$ 25 \text { mill. }\end{array}$} & \multicolumn{2}{|c|}{$\begin{array}{l}\text { Index }{ }^{1} \\
\text { Portfolio } \\
\text { Return Std }\end{array}$} & \multicolumn{2}{|c|}{$\begin{array}{l}\text { Low P/E } \\
\text { Portfolio } \\
\text { Return Std }\end{array}$} & \multicolumn{2}{|c|}{$\begin{array}{l}\text { Low P/B } \\
\text { Portfolio } \\
\text { Return Std }\end{array}$} & \multicolumn{2}{|c|}{$\begin{array}{l}\text { Low P/S } \\
\text { Portfolio } \\
\text { Return Std }\end{array}$} & \multicolumn{2}{|c|}{$\begin{array}{l}\text { Low P+D / S } \\
\text { Portfolio } \\
\text { Return Std }\end{array}$} & \multicolumn{2}{|c|}{$\begin{array}{l}\text { Portfolio } \\
\text { Return Std }\end{array}$} & \multicolumn{2}{|l|}{$\begin{array}{l}\text { Portfolio } \\
\text { Return S }\end{array}$} \\
\hline & 0.252 & 1.471 & 0.442 & 1.524 & 0.405 & 1.175 & 0.784 & 4.158 & 0.602 & 3.912 & 0.829 & 3.932 & 0.692 & 3.924 \\
\hline $\begin{array}{l}\text { Mini-cap } \\
\$ 25-\$ 100 \mathrm{mi}\end{array}$ & $\begin{array}{l}0.102 \\
\text { iill }\end{array}$ & 0.717 & 0.201 & 0.515 & 0.100 & 0.412 & 0.258 & 1.767 & 0.254 & 1.481 & 0.256 & 1.712 & 0.205 & 1.372 \\
\hline $\begin{array}{l}\text { Small-cap } \\
\$ 100-500 \mathrm{mi}\end{array}$ & $\begin{array}{l}0.092 \\
\text { iill. }\end{array}$ & 0.487 & 0.187 & 0.522 & 0.151 & 0.379 & 0.191 & 0.912 & 0.168 & 0.522 & 0.218 & 0.816 & 0.156 & 0.381 \\
\hline $\begin{array}{l}\text { Mid-cap } \\
\$ 500-\$ 1 \text { bill. }\end{array}$ & 0.116 & 0.448 & 0.138 & 0.301 & 0.137 & 0.312 & 0.124 & 0.409 & 0.126 & 0.401 & 0.143 & 0.401 & 0.118 & 0.292 \\
\hline $\begin{array}{l}\text { Large-cap } \\
>\$ 1 \text { bill. }\end{array}$ & 0.117 & 0.325 & 0.139 & 0.307 & 0.182 & 0.323 & 0.175 & 0.329 & 0.181 & 0.289 & 0.185 & 0.291 & 0.151 & 0.284 \\
\hline $\begin{array}{l}\text { All-cap } \\
>\$ 100 \mathrm{mil}\end{array}$ & 0.111 & 0.444 & 0.182 & 0.418 & 0.171 & 0.427 & 0.236 & 0.842 & 0.175 & 0.299 & 0.259 & 0.802 & 0.142 & 0.346 \\
\hline
\end{tabular}

Note: All portfolios include only non-financial stocks with a December 31 fiscal year-end.

${ }^{1}$ All stocks.

${ }^{2} 25$ stocks with the lowest price-to-earnings ratios.

${ }^{3} 25$ stocks with the lowest price-to-book value of equity ratios.

${ }^{4} 25$ stocks with the lowest price-to-sales ratios.

${ }^{5} 25$ stocks with the lowest (price + long-term debt)-to-sales ratios.

${ }^{6} 25$ stocks with the lowest price-to-sales (adjusted for profit margin) ratios.

${ }^{7} 25$ stocks with the lowest (price + long-term debt)-to-sales (adjusted for profit margins) ratios. 
TABLE 2

STATISTICAL RESULTS OF T-TESTS FOR THE PORTFOLIO RETURNS

\section{Panel A}

Index

vs.

Price / Earnings Ratio

Price / Book Ratio

Price / Sales Ratio

Price + Debt / Sales Ratio

Price / Sales x PM Ratio

Price + Debt / Sales $\times$ PM Ratio

$\begin{array}{llllll}\text { Micro-Cap } & \text { Mini-Cap } & \text { Small-Cap } & \text { Mid-Cap } & \text { Large-Cap } & \text { All-Cap } \\ & & & & & \\ -2.252^{* *} & -2.132 * * & -1.742^{* *} & -0.047 & -0.128 & -1.365^{*} \\ -2.283^{* *} & 0.364 & -1.109 & -0.113 & -1.351 * & -0.963 \\ -1.865 * * & -1.649^{*} & -1.741^{* *} & -0.461 & -1.407 * & -1.816^{* *} \\ -1.667^{*} & -1.788^{* *} & -1.637^{*} & -0.442 & -1.398 * & -1.616^{*} \\ -2.021 * * & -1.654^{*} & -2.053^{* *} & -0.109 & -1.9222^{* *} & -2.013^{* *} \\ -1.901 * * & -1.356 * & -1.812^{* *} & -0.672 & -0.389 & -0.818\end{array}$

\section{Panel B}

Price / Earnings ratio

vs.

Price / Book Ratio

Price / Sales Ratio

Price + Debt / Sales Ratio

Price / Sales x PM Ratio

Price + Debt / Sales x PM Ratio

$$
\begin{array}{r}
0.085 \\
0.265 \\
0.313 \\
-0.212 \\
0.875
\end{array}
$$

\section{Panel C}

Price / Book Ratio

vs.

Price / Sales Ratio

Price + Debt / Sales Ratio

Price / Sales x PM Ratio

Price + Debt / Sales x PM Ratio

$$
\begin{array}{lll}
-1.378 * & -1.814 * * & -1.026 \\
-1.044 & -1.942 * * & -0.411 \\
-1.664 * & -1.807 * * & -1.249
\end{array}
$$

$-1.298 \quad-1.591$ * 0.113

$$
\begin{array}{r}
0.245 \\
0.276 \\
-0.235 \\
0.623
\end{array}
$$

$$
\begin{array}{r}
0.317 \\
0.013 \\
-0.313
\end{array}
$$

1.132

$-1.126$

0.139

-1.421 *

0.613

\section{Panel D}

Price / Sales Ratio

vs.

Price + Debt / Sales Ratio

Price / Sales x PM Ratio

Price + Debt / Sales x PM Ratio

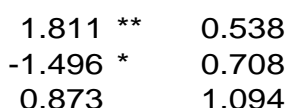

0.919
-0.516

1.247

-0.024
-0.412
0.357

-0.297
-0.018

1.328 *

0.873

1.094
$-0.493$

1.599 *

** .05 level of significance

$\star .10$ level of significance 